\title{
EVALUATION OF RENAL CHANGES IN SICKLE CELL DISEASE IN A REFERRAL GOVERNMENT INSTITUTE OF SOUTHERN ODISHA
}

\author{
BIJAYA KUMAR BEHERA ${ }^{1}$, SUSANTA SEKHAR BEHERA ${ }^{1}$, SUKANTA KUMAR JENA ${ }^{2}$, RAKESH MOHANTY ${ }^{1}$, \\ NISARG BEHERA ${ }^{1 *}$
}

${ }^{1}$ Department of General Medicine, MKCG Medical College and Hospital, Berhampur, Odisha, India. ${ }^{2}$ Department of Radiodiagnosis, MKCG Medical College and Hospital, Berhampur, Odisha, India. Email: ronnie.nisarg@gmail.com

Received: 08 August 2021, Revised and Accepted: 06 October 2021

ABSTRACT

Objective: The objective of the study was to study various renal manifestations in sickle cell disease (SCD) and to establish a cause and effect relationship with the evaluation of risk factors.

Methods: This prospective observational cross-sectional study was conducted on 82 SCD patients belonging to the age group of 15-50 years of both the genders over a period of 2 years from January 2019 to December 2020 in MKCG Medical College and Hospital, Berhampur, Odisha, India. Eighty-two patients, 32 (39.02\%) having sickle cell anemia (SCA) and 50 (60.98\%) having sickle cell trait (SCT), admitted to medicine and nephrology wards of the hospital were included in this study. SCD patients with other hemolytic anemia and with renal congenital/structural abnormality and patients with systemic diseases such as diabetes mellitus, systemic hypertension, and systemic lupus erythematosus were excluded from the study. Various laboratory investigations such as complete blood count, hemoglobin (Hb), serum sodium, serum potassium, serum urea, serum creatinine, fasting blood sugar, erythrocyte sedimentation rate, liver function test, urine routine, and microscopic test were carried out. Diagnosis of SCD patients was based on sickling test and high-performance liquid chromatography testing. Radiologic imaging (Sonography for renal changes) was done at radiodiagnosis department of the hospital.

Results: Glomerular and tubular dysfunction was more in SCA (Hb SS) patients than SCT (Hb AS) patients and the abnormality was more in patients in crisis. Albuminuria in $78.12 \%$, hematuria in $46.87 \%$, cast and crystal in $28.12 \%$, epithelial cell in $31.25 \%$, and hyposthenuria in $56.25 \%$ were found in SCA patients. In SCT patients, albuminuria in 38\%, hematuria in 16\%, cast and crystal in $22 \%$, epithelial cell in $12 \%$, and hyposthenuria in $24 \%$ were found. All the above findings were more in percentages in crisis patients of both the groups. In SCA, 37.5\% and in SCT, $2 \%$ were found to have chronic kidney disease.

Conclusion: Renal involvement in the form of glomerular and tubular dysfunction occur in SCD and more in crisis patients, leading to renal complications, and end-stage renal disease.

Keywords: Sickle cell disease, Sickle cell anemia, Sickle cell trait, Chronic kidney disease.

(c) 2021 The Authors. Published by Innovare Academic Sciences Pvt Ltd. This is an open access article under the CC BY license (http://creativecommons.org/ licenses/by/4.0/) DOI: http://dx.doi.org/10.22159/ajpcr.2021v14i11.42869. Journal homepage: https://innovareacademics.in/journals/index.php/ajpcr

\section{INTRODUCTION}

Sickle cell disease (SCD) is an autosomal recessive hemoglobin disorder, predominantly affecting persons of African, Mediterranean, Indian and Middle Eastern descent. It occurs due to replacement of glutamic acid for valine at the sixth amino acid of the beta-globin chain. This mutation results in hemoglobin $\mathrm{S}(\mathrm{Hb} \mathrm{S}$ ) tetramers that accumulate during tissue hypoxia, oxidative stress, or dehydration. The accumulation leads to red blood cell sickling, early destruction of erythrocytes, and wide spread vaso-occlusive episodes, subsequently resulting in multi organ damage.

SCD was first discovered in West Africa. An estimated seven percent of the world population carry an abnormal hemoglobin gene, while about three lakhs to five lakhs are born annually with significant hemoglobin disorder. Sickle cell syndrome is more frequent and constitutes $70 \%$ of affected births worldwide, the rest are due to thalassemias [1]. SCD affects many communities in India in certain regions, such as Central India (Deccan Region) and states of Gujarat, Maharashtra, and Kerala. The carrier frequency of the sickle cell gene varies from one percent to $35 \%$ and hence there are a huge number of SCD [2].

It has been observed that $11.1 \%$ in hospital patients of Western Odisha were sickle cell positive and the gene was found to be widespread in the state [3]. Renal complications, collectively known as sickle cell nephropathy (SCN), are among the most common complications of SCD and are the well-known cause of morbidity and mortality in SCD and the incidence of renal failure increases as patient survival improves, thus being a great challenge to the health care professionals of providing adequate services for treatment of SCD. SCN includes hematuria, proteinuria, hyposthenuria, renal papillary necrosis, renal tubular disorders, acute and chronic kidney injury, sickle cell glomerulopathy, and renal medullary carcinoma. Clinically significant renal involvement occurs more frequently in sickle cell anemia (SCA) than in sickle cell trait (SCT) or in combined hemoglobinopathies, except renal medullary carcinoma, which appears to be more common among SCT patients [4]. Platt et al. provided the most comprehensive analysis on life expectancy and risk factors for early death in SCD; $18 \%$ of deaths are ascribed to chronic end-organ involvement, predominantly renal [5].

Considering the magnitude of the SCD patients in this part of the country and as very few studies have been done in our region on SCN, it was considered worthwhile to undertake this present study for a better understanding of renal changes that may be found in SCD patients. The objective of this study was to evaluate various renal manifestations in SCD and to establish a cause and effect relationship with risk factors.

\section{METHODS}

A prospective observational cross-sectional study was designed in the Department of General Medicine and Nephrology in MKCG Medical 
College and Hospital, Berhampur, Odisha, India over a period of 2 years from January 2019 to December 2020. A total number of 82 SCD patients belonging to the age group of 15-50 years of both the genders admitted to Medicine and Nephrology wards and diagnosed as a case of SCA $(n=32 ; 39.02 \%)$ or SCT $(n=50 ; 60.98 \%)$ according to clinical and hematological investigation fulfilling the inclusion, exclusion criteria were taken for the study.

\section{Inclusion criteria}

All patients with SCA or SCT, admitted in the departments of medicine and nephrology were included in this study.

\section{Exclusion criteria}

SCD patients with other hemolytic anemia and with renal congenital/structural abnormality and patients with systemic disease such as diabetes mellitus, systemic hypertension, and systemic lupus erythematosus were excluded from the study.

The study was conducted after the study protocol was approved by the Institutional Ethics Committee (No 765/Chairman-IEC, MKCG Medical college, Brahmapur-4). Informed consent was obtained from all the patients in accordance with the guidelines of the Declaration of Helsinki 2008. Patients were screened based on inclusion and exclusion criteria and selected patients were thoroughly examined. The evaluation was comprised detailed history, physical examination, and relevant investigations. Height, weight, and BMI were measured for every patient. Various laboratory investigations such as complete blood count, $\mathrm{Hb}$, serum sodium, serum potassium, serum urea, serum creatinine, fasting blood sugar, erythrocyte sedimentation rate, liver function test, and urine routine microscopic test were done at Regional Diagnostic Centre of our hospital. Patients were diagnosed SCD based on sickling test and high-performance liquid chromatography testing.

Radiologic imaging (Sonography for renal changes) was done at Radiodiagnosis department of the hospital. The acute changes in the kidney were examined with ultrasound. Computed tomography and magnetic resonance imaging were used for the follow-up examinations. In evaluation of the acute changes in the kidney, the echogenicity of the renal structure, the delineation of the kidney, the renal vascularity, kidney size, and focal abnormalities were observed. Ultrasound was useful for diagnostic and prognostic purposes in chronic kidney disease (CKD).

In the present study, estimated glomerular filtration rate (eGFR) was assessed separately in adults and adolescents ( $<17$ years) using CKD-EPI equation (2009) and Schwartz equation (2009), respectively.

eGFR (CKD-EPI equation, 2009):

eGFR $=141 \times \min \left(\mathrm{S}_{\mathrm{cr}} / \mathrm{K}, 1\right)^{\alpha} \times \max \left(\mathrm{S}_{\mathrm{cr}} / \mathrm{K}, 1\right)^{-1.209} \times 0.993^{\mathrm{Age}^{\mathrm{Ag}} \times 1.018}$ [if female]

$=141 \times \min \left(\mathrm{S}_{\mathrm{Cr}} / \mathrm{K}, 1\right)^{\alpha} \times \max \left(\mathrm{S}_{\mathrm{Cr}} / \mathrm{K}, 1\right)^{-1.209} \times 0.993^{\mathrm{Age}} \times 1.159$ [if black]

Abbreviations/Units:

eGFR: Estimated glomerular filtration rate $\left(\mathrm{ml} / \mathrm{min} / 1.73 \mathrm{~m}^{2}\right)$

$\mathrm{S}_{\mathrm{cr}}$ : Standardized serum creatinine $(\mathrm{mg} / \mathrm{dL})$

$\mathrm{K}=0.7$ (females) or 0.9 (males)

$\alpha=-0.329$ (females) or -0.411 (males)

min: indicates the minimum of $S_{c r} / K$ or 1

max: indicates the maximum of $\mathrm{S}_{\mathrm{rr}} / \mathrm{K}$ or 1

Age: in years

Schwartz equation (2009):

$\mathrm{eGFR}=0.413 \times\left(\right.$ Height $\left./ \mathrm{S}_{\mathrm{Cr}}\right)$ (height is expressed in centimeter)

CKD was diagnosed and classified according to 2012 kidney disease improving global outcomes criteria. Patients with persistent urinary anomalies or decreased eGFR at 3 months were considered to have CKD.

a. Stage 1: Normal; eGFR $>90 \mathrm{ml} / \mathrm{min} / 1.73 \mathrm{~m}^{2}$

b. Stage 2: Mild kidney damage; eGFR $=60-89 \mathrm{ml} / \mathrm{min} / 1.73 \mathrm{~m}^{2}$

c. Stage 3: Moderate kidney damage; eGFR $=30-59 \mathrm{ml} / \mathrm{min} / 1.73 \mathrm{~m}^{2}$

d. Stage 4: Severe kidney damage; eGFR $=15-29 \mathrm{ml} / \mathrm{min} / 1.73 \mathrm{~m}^{2}$

e. Stage 5: Kidney failure; eGFR $\leq 15 \mathrm{ml} / \mathrm{min} / 1.73 \mathrm{~m}^{2}$
Further, patients with eGFR $>140 \mathrm{ml} / \mathrm{min} / 1.73 \mathrm{~m}^{2}$ are denoted as glomerular hyperfiltration, eGFR $<89$ to $60 \mathrm{ml} / \mathrm{min} / 1.73 \mathrm{~m}^{2}$ as renal insufficiency (RI) and eGFR $<59 \mathrm{ml} / \mathrm{min} / 1.73 \mathrm{~m}^{2}$ as renal failure (RF).

\section{Statistical analysis}

Data were entered using Microsoft Excel and all statistical analysis was performed using Statistical Package for the Social Sciences, version 17.0. Basic descriptive statistics were computed for the demographic data. Values were expressed as mean \pm (SD)/or proportion (percentage) with statistical significance set at $p$-value $<0.05(p<0.05)$ was considered statistically significant, $p<0.01$ was highly significant, and $p<0.001$ was very highly significant.

\section{RESULTS}

Maximum number of cases was clustered in the age group of 15-25 years $(58.54 \%)$, followed by in the age group of $26-35$ years (26.97\%). There were only $9(10.98 \%)$ cases in the age group of 36-45 years. Among them, one case $(1.22 \%)$ was SCA and eight cases $(9.76 \%)$ were SCT. There was only one case above age 45 years that belong to SCT (Table 1 ). The result was statistically highly significant $(\mathrm{p}=0.009)$ (Table 1$)$.

Out of total 32 males, maximum numbers $(n=17,53.12 \%)$ were in the age group of 15-25 years, and out of total 50 females, and maximum numbers $(n=31,62.01 \%)$ were also in the age group of $15-25$ years. $\mathrm{p}$-value of the above table data is 0.57 and is non-significant (Table 2).

Out of 82 cases of SCD patients, 21 patients presented with sickle cell crisis were studied. Male: female ratio in total study population with crisis was $0.4: 1$, that is, six cases $(28.57 \%)$ were males and 15 cases $(71.42 \%)$ were females. In AS pattern with crisis 7 cases $(77.78 \%)$ out of nine cases were females, also in SS pattern with crisis maximum number of cases, 8 cases $(66.66 \%)$ were females out of 12 cases. Out of 21 patients of sickle cell crisis, maximum number of patients, 14 patients $(66.67 \%)$ were in the age group of 15-25 years followed by four patients $(19.04 \%)$ in the age group of $26-35$ years. In the SCT patients with crisis equal number of cases, that is, 3 each (33.33\%) were in the age group of $15-25,26-35$, and 36-45 years. Among 12 patients of SS pattern with crisis, maximum number of cases 8 cases $(66.66 \%)$ was females and they were in the age group of 15-25 years (Table 3).

Among the SCA patients, majority of the participants 19 (59.37\%) had $\mathrm{Hb}$ level of range $5-7 \mathrm{~g} / \mathrm{dl}$ and for SCT, majority $20(40 \%)$ had $\mathrm{Hb}$ of level 7-9 g/dl. The difference of $\mathrm{Hb}$ level among two groups was found to be very highly significant $(\mathrm{p}<0.001)$ (Table 4$)$. Among the SCA the mean $\mathrm{Hb}$ level was $6.3( \pm 0.89) \mathrm{g} / \mathrm{dl}$ and for SCT it was $9( \pm 0.48) \mathrm{g} / \mathrm{dl}$ (Fig. 1).

Table 1: Age distribution among the study participants in two groups of SCD

\begin{tabular}{lllll}
\hline $\begin{array}{l}\text { Age groups } \\
\text { in years }\end{array}$ & SCA (\%) & SCT (\%) & Total (\%) & p-value \\
\hline $15-25$ & $26(31.71)$ & $22(26.83)$ & $48(58.54)$ & $0.009^{* *}$ \\
$26-35$ & $5(6.10)$ & $19(23.17)$ & $24(29.27)$ & \\
$36-45$ & $1(1.22)$ & $8(9.76)$ & $9(10.98)$ & \\
$46-50$ & $0(0.00)$ & $1(1.22)$ & $1(1.22)$ & \\
Total & $32(39.02)$ & $50(60.98)$ & $82(100.00)$ & \\
\hline
\end{tabular}

*Significant at $\mathrm{P}<0.05,{ }^{* *}$ Highly significant at $\mathrm{P}<0.01,{ }^{* * *}$ Very highly significant at $\mathrm{P}<0.001$, SCD: Sickle cell disease, SCA: Sickle cell anemia, SCT: Sickle cell trait

Table 2: Age- and gender-wise distribution of sickle cell patients

\begin{tabular}{lllll}
\hline $\begin{array}{l}\text { Age group } \\
\text { (years) }\end{array}$ & $\begin{array}{l}\text { Total } \\
(\mathbf{n = 8 2 )}(\mathbf{6})\end{array}$ & $\begin{array}{l}\text { Female } \\
(\mathbf{n = 5 0 )}(\%)\end{array}$ & $\begin{array}{l}\text { Male } \\
(\mathbf{n = 3 2})(\%)\end{array}$ & p-value \\
\hline $15-25$ & $48(58.5)$ & $31(62.0)$ & $17(53.1)$ & 0.57 \\
$26-35$ & $24(29.3)$ & $14(28.0)$ & $10(31.2)$ & \\
$36-45$ & $9(11.0)$ & $4(8.0)$ & $5(15.6)$ & \\
$46-50$ & $1(1.2)$ & $1(2.0)$ & $0(0.0)$ & \\
\hline
\end{tabular}

*Significant at $\mathrm{P}<0.05,{ }^{* *}$ Highly significant at $\mathrm{P}<0.01,{ }^{* * *}$ Very highly significant at $\mathrm{P}<0.001$ 
Table 3: Age- and gender-wise distribution of patients with sickle cell crisis

\begin{tabular}{|c|c|c|c|c|c|c|}
\hline \multirow[t]{2}{*}{ Age Groups } & \multicolumn{2}{|l|}{ SCA (\%) } & \multicolumn{2}{|l|}{ SCT (\%) } & \multicolumn{2}{|l|}{ Overall (\%) } \\
\hline & Female $(n=8)$ & Male $(n=4)$ & Female $(n=7)$ & Male $(n=2)$ & Female $(n=15)$ & Male $(n=6)$ \\
\hline $15-25$ & $8(100)$ & $3(75.0)$ & $2(28.6)$ & $1(50.0)$ & $10(66.7)$ & $4(66.7)$ \\
\hline $26-35$ & $0(0)$ & $1(25.0)$ & $3(42.9)$ & $0(0)$ & $3(20.0)$ & $1(16.7)$ \\
\hline $36-45$ & $0(0)$ & $0(0)$ & $2(28.6)$ & $1(50.0)$ & 2 (13.3) & $1(16.7)$ \\
\hline $46-50$ & $0(0)$ & $0(0)$ & $0(0)$ & $0(0)$ & $0(0)$ & $0(0)$ \\
\hline
\end{tabular}

SCA: Sickle cell anemia, SCT: Sickle cell trait

Table 4: Anemia in patients with SCD

\begin{tabular}{llll}
\hline Hb level & SCA $(\mathbf{n = 3 2 )}(\mathbf{\%})$ & SCT $(\mathbf{n = 5 0 )}(\%)$ & p-value \\
\hline$>9 \mathrm{~g} / \mathrm{dl}$ & $1(3.12)$ & $18(36)$ & $<0.001^{* * *}$ \\
$7-9 \mathrm{~g} / \mathrm{dl}$ & $12(37.5)$ & $20(40)$ & \\
$5-7 \mathrm{~g} / \mathrm{dl}$ & $19(59.37)$ & $12(24)$ & \\
\hline
\end{tabular}

*Significant at $\mathrm{P}<0.05$, **Highly significant at $\mathrm{P}<0.01,{ }^{* * *}$ Very highly significant at $\mathrm{P}<0.001, \mathrm{Hb}$ : Hemoglobin, SCA: Sickle cell anemia, SCT: Sickle cell trait, SCD: Sickle cell disease,

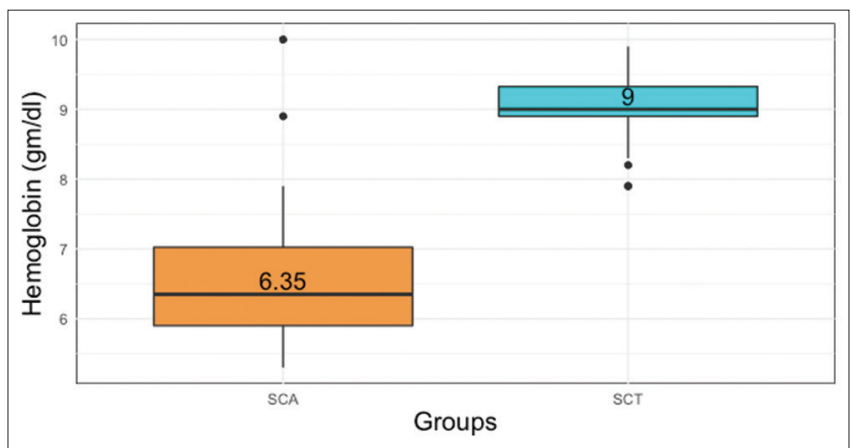

Fig. 1: Mean hemoglobin between two groups of sickle cell disease

In Table 5, it was found that maximum number of female cases ( $\mathrm{n}=19,38 \%$ ) was having low Hb level 5-7 g/dl. Maximum number of male cases ( $\mathrm{n}=14,43.8 \%$ ) had Hb level 7-9 g/dl.

The major clinical symptoms among the study participants were fatigability, dyspnea, pallor, and icterus. Out of 82 participants, 41 (50\%) complained of fatigability, 21 (25.6\%) complained of dyspnea, and $23(28.0 \%)$ were having icterus. Nearly all participants had pallor. There were significant differences between SCA and SCT with respect to clinical symptoms such as fatigability, dyspnea, and icterus. Out of 32 SCA patients, 27 (84.4\%) complained of fatigability and out of 50 SCT patients, $14(28.0 \%)$ had fatigability. This difference was statistically very highly significant $(\mathrm{p}<0.001)$ (Table 6).

Similarly, 13 (40.6\%) out of 32 patients of SCA and eight $(16.0 \%)$ out of 50 patients of SCT were having dyspnea as the clinical symptoms. This difference was found to be statistically highly significant $(\mathrm{p}<0.013)$ (Table 6). Icterus was seen among 16 (50.0\%) patients of SCA and seven $(14.0 \%)$ of SCT patients. This difference was found to be statistically very highly significant $(\mathrm{p}<0.001)$ (Table 6 and Fig. 2).

In SCA, 16 (50\%) cases had microalbuminuria and nine (28.1\%) cases had macroalbuminuria. In SCT, 12 (24\%) cases had microalbuminuria and seven $(14 \%)$ cases had macroalbuminuria among these data microalbuminuria shows significant p-value (0.015) when compared between SCA and SCT patients (Table 7).

Microscopic hematuria was a predominant finding in patients of SS pattern, that is, 15 cases $(46.87 \%)$ of total 32 cases. On the other hand, among the patients with AS pattern eight cases (16\%) had hematuria. This data were significant having $\mathrm{p}$-value $<0.05$ (Table 7).
Similarly cast and crystals in urine were found in nine cases $(28.12 \%)$ of SS pattern and 11 cases (22\%) of AS pattern. Out of total population, eight patients $(9.7 \%)$ had RBC casts, while 18 patients $(21.95 \%)$ had granular casts. Five cases $(15.6 \%)$ of SS pattern had significant number of pus cells in their urine. Ten cases (31.2\%) of SS pattern and six cases $(12 \%)$ of AS pattern had epithelial cells in urine (Table 7).

Two cases $(22.2 \%)$ of SCT pattern and 11 cases (91.9\%) of SCA pattern with crisis had hematuria. This data show a p value of 0.001 and is highly significant. Out of 21 patients with sickle cell crisis, ten cases (48\%) had significant albuminuria, out of which one case $(10 \%)$ was of SCT pattern with crisis and nine cases (90\%) were of SCA pattern with crisis. For microalbuminuria the data has significant p-value (0.027). Nine cases $(100 \%)$ of SCT pattern with crisis had casts and crystals in urine. There were six cases (50\%) of SS pattern with crisis who had casts and crystals. Casts were mostly granular cast, followed by RBC casts ( $p$-value $=0.01$ ). This data have statistical significance showing cast and crystals found more in urine in patients of SCA with crisis. There were seven cases (58.3\%) of SCA pattern with crisis who had tubular epithelial cells in their urine microscopy, suggesting tubular damage; while none of the patients of SCT pattern with crisis had tubular epithelium in their urine microscopy $(p=0.001)$ and is highly significant (Table 8). In SCA patients five (41.7\%) cases had pus cells in urine while none of the SCT patients had pus cells.

Out of 82 SCD patients, 42 patients (51.2\%) had normal urinary specific gravity, while 40 patients ( $48.8 \%$ ) had abnormal urinary specific gravity. $18(56.2 \%)$ patients of SCA pattern had hyposthenuria and $12(24.0 \%)$ patients of SCT pattern had hyposthenuria. Seven $(21.9 \%)$ patients of SCA pattern had hypersthenuria and three $(6.0 \%)$ of SCT pattern had hypersthenuria, $(\mathrm{p}<0.001)$ and is very highly significant (Table 9$)$.

In 21 patients with sickle cell crisis nine (42.9\%) had developed hyposthenuria out of which two cases $(22.2 \%)$ were SCT patients and seven cases $(58.33 \%)$ were SCA patients, p-value=0.019, suggesting significant data (Table 10).

In this study, $12(37.5 \%)$ cases of SCA were found to have CKD and one $(2 \%)$ case of SCT has CKD. This data show a p-value of $<0.001$ and are very highly significant (Table 11 and Fig. 3).

Seven (58.3\%) cases of SCA patients with crisis and one $(11.12 \%)$ case of SCT patients with crisis were found to have CKD by that time. Also highly significant p-value in relation to CKD in patients of SCA and SCT with crisis was found to be 0.027 (Table 12 and Fig. 4).

\section{DISCUSSION}

Advances in epidemiologic and genetic research in SCD have made it possible to understand the sickle-Hb-related nephropathy comprehensibly and thereby helping the individuals with sickle hemoglobinopathies. This study was made to determine the prevalence of CKD amongst patients with SCD and risk factor contributing to its development.

All cases belonging to the present study were in the age group of $15-50$ years with mean age of $25.28 \pm 8.93$ years. Maximum number of cases was clustered in the age group of 15-25 years which correlates well with the demographic pattern of our country and with some other 
Table 5: Gender-wise distribution of anemia

\begin{tabular}{lllll}
\hline $\begin{array}{l}\text { Hb } \\
\text { Classification }\end{array}$ & $\begin{array}{l}\text { Female } \\
(\mathbf{n = 5 0 )}(\mathbf{\%})\end{array}$ & $\begin{array}{l}\text { Male } \\
(\mathbf{n = 3 2}) \mathbf{( \% )}\end{array}$ & $\begin{array}{l}\text { Total } \\
(\mathbf{n = 8 2 )} \mathbf{( \% )}\end{array}$ & p-value \\
\hline$>9 \mathrm{~g} / \mathrm{dl}$ & $13(26.0)$ & $6(18.8)$ & $19(23.2)$ & 0.689 \\
$5-7 \mathrm{~g} / \mathrm{dl}$ & $19(38.0)$ & $12(37.5)$ & $31(37.8)$ & \\
$7-9 \mathrm{~g} / \mathrm{dl}$ & $18(36.0)$ & $14(43.8)$ & $32(39.0)$ & \\
\hline
\end{tabular}

*Significant at $\mathrm{P}<0.05$, **Highly significant at $\mathrm{P}<0.01,{ }^{* * *}$ Very highly significant at $\mathrm{P}<0.001$, Hb: Hemoglobin

Table 6: Clinical signs and symptoms among the study participants between two groups

\begin{tabular}{|c|c|c|c|c|}
\hline $\begin{array}{l}\text { Signs and } \\
\text { Symptoms }\end{array}$ & $\begin{array}{l}\text { SCA Mean } \\
(\mathrm{SD}), \\
(n=32)(\%)\end{array}$ & $\begin{array}{l}\text { SCT Mean } \\
(\mathrm{SD}), \\
(n=50)(\%)\end{array}$ & $\begin{array}{l}\text { Total Mean } \\
(S D), \\
(n=82)(\%)\end{array}$ & p-value \\
\hline \multicolumn{5}{|l|}{ Fatigability } \\
\hline No & $5(15.6)$ & $36(72.0)$ & $41(50.0)$ & \multirow[t]{2}{*}{$<0.001^{* * *}$} \\
\hline Yes & $27(84.4)$ & $14(28.0)$ & $41(50.0)$ & \\
\hline \multicolumn{5}{|l|}{ Dyspnea } \\
\hline No & $19(59.4)$ & $42(84.0)$ & $61(74.4)$ & \multirow[t]{2}{*}{$0.013^{*}$} \\
\hline Yes & $13(40.6)$ & $8(16.0)$ & $21(25.6)$ & \\
\hline \multicolumn{5}{|l|}{ Pallor } \\
\hline Yes & $32(100)$ & $50(100)$ & 76 (92.7) & 0.567 \\
\hline \multicolumn{5}{|l|}{ Icterus } \\
\hline No & $16(50.0)$ & $43(86.0)$ & $59(72.0)$ & \multirow[t]{2}{*}{$<0.001^{* * *}$} \\
\hline Yes & $16(50.0)$ & $7(14.0)$ & 23 (28.0) & \\
\hline
\end{tabular}

*Significant at $\mathrm{P}<0.05,{ }^{* *}$ Highly significant at $\mathrm{P}<0.01,{ }^{* * *}$ Very highly significant at $\mathrm{P}<0.001$, SCA: Sickle cell anemia, SCT: Sickle cell trait

Table 7: Physical and microscopic urine analysis of the study participants among two groups

\begin{tabular}{|c|c|c|c|c|}
\hline Parameters & $\begin{array}{l}\text { SCA } \\
(n=32) \\
(\%)\end{array}$ & $\begin{array}{l}\text { SCT } \\
(n=50) \\
(\%)\end{array}$ & $\begin{array}{l}\text { Total } \\
(n=82) \\
(\%)\end{array}$ & p-value \\
\hline \multicolumn{4}{|l|}{ Micro-albuminuria } & $0.015^{*}$ \\
\hline No & $16(50.0)$ & $38(76.0)$ & $54(65.9)$ & \\
\hline Yes & $16(50.0)$ & $12(24.0)$ & $28(34.1)$ & \\
\hline \multicolumn{4}{|c|}{ Macro-albuminuria } & 0.115 \\
\hline No & $23(71.9)$ & $43(86.0)$ & $66(80.5)$ & \\
\hline Yes & $9(28.1)$ & $7(14.0)$ & $16(19.5)$ & \\
\hline \multicolumn{4}{|l|}{ Hematuria } & $0.002^{* *}$ \\
\hline No & $17(53.1)$ & $42(84.0)$ & $59(80.5)$ & \\
\hline Yes & $15(46.8)$ & $8(16.0)$ & $23(19.5)$ & \\
\hline \multicolumn{4}{|c|}{ Cast and crystals in urine } & 0.297 \\
\hline Granular & $4(12.5)$ & $8(16.0)$ & $12(14.6)$ & \\
\hline No & $23(71.9)$ & $39(78.0)$ & $62(75.6)$ & \\
\hline $\mathrm{RBC}$ & $2(6.2)$ & $0(0.0)$ & $2(2.4)$ & \\
\hline RBC and Granular & $3(9.4)$ & $3(6.0)$ & $6(7.3)$ & \\
\hline \multicolumn{4}{|l|}{ Epithelial cells } & $0.032^{*}$ \\
\hline No & $22(68.8)$ & $44(88.0)$ & $66(80.5)$ & \\
\hline Yes & $10(31.2)$ & $6(12.0)$ & $16(19.5)$ & \\
\hline \multicolumn{4}{|l|}{ Pus cells } & $0.004^{* *}$ \\
\hline No & 27 (84.4) & $50(100.0)$ & 77 (93.9) & \\
\hline Yes & $5(15.6)$ & $0(0.0)$ & $5(6.1)$ & \\
\hline
\end{tabular}

*Significant at $\mathrm{P}<0.05,{ }^{* *}$ Highly significant at $\mathrm{P}<0.01,{ }^{* * *}$ Very highly significant at $\mathrm{P}<0.001, \mathrm{SCA}$ : Sickle cell anemia, SCT: Sickle cell trait, RBC: Red blood cell

findings in the previous studies such as Khan and Patil, Andhale et al., and Dhumne and Jawade [6-8]. There was low prevalence of SCD in higher age group due to the small sample size and the fact that most of the sickle cell patients succumbed in early ages due to the disease [6]. But in countries with access to organized healthcare, survival of children with SCD has greatly improved resulting in a growing population of adults with SCD [9].

Male: female ratio in the present study population was $0.64: 1$, while that of SCA pattern and SCT pattern were 0.88:1 and 0.51:1, respectively. This
Table 8: Physical and Microscopic urine analysis of sickle cell crisis patients

\begin{tabular}{|c|c|c|c|c|}
\hline Parameters & $\begin{array}{l}\text { SCA } \\
(n=12) \\
(\%)\end{array}$ & $\begin{array}{l}\text { SCT } \\
(n=9) \\
(\%)\end{array}$ & $\begin{array}{l}\text { Total } \\
(n=21) \\
(\%)\end{array}$ & p-value \\
\hline \multicolumn{4}{|l|}{ Microalbuminuria } & $0.027^{*}$ \\
\hline No & $7(58.3)$ & $9(100.0)$ & $16(76.2)$ & \\
\hline Yes & 5 (41.7) & $0(0.0)$ & $5(23.8)$ & \\
\hline \multicolumn{4}{|c|}{ Macro-albuminuria } & 0.237 \\
\hline No & $8(66.7)$ & $8(88.9)$ & $16(76.2)$ & \\
\hline Yes & $4(33.3)$ & $1(11.1)$ & $5(23.8)$ & \\
\hline \multicolumn{4}{|l|}{ Hematuria } & $0.001^{* *}$ \\
\hline No & $1(8.3)$ & $7(77.8)$ & $8(38.1)$ & \\
\hline yes & $11(91.7)$ & $2(22.2)$ & $13(61.9)$ & \\
\hline \multicolumn{4}{|c|}{ Cast and crystals in urine } & $0.01^{*}$ \\
\hline Granular & $1(8.3)$ & $4(44.4)$ & $5(23.8)$ & \\
\hline No & $6(50.0)$ & $2(22.2)$ & $8(38.1)$ & \\
\hline $\mathrm{RBC}$ & $2(16.7)$ & $0(0.0)$ & $2(9.5)$ & \\
\hline RBC and Granular & $3(25.0)$ & $3(33.3)$ & $6(28.6)$ & \\
\hline \multicolumn{4}{|l|}{ Epithelial cells } & $0.005^{* *}$ \\
\hline No & $5(41.7)$ & $9(100.0)$ & $14(66.7)$ & \\
\hline Yes & $7(58.3)$ & $0(0.0)$ & $7(33.3)$ & \\
\hline \multicolumn{4}{|l|}{ Pus Cells } & $0.027^{*}$ \\
\hline No & 7 (58.3) & $9(100.0)$ & $16(76.2)$ & \\
\hline Yes & 5 (41.7) & $0(0.0)$ & $5(23.8)$ & \\
\hline
\end{tabular}

Table 9: Specific gravity of urine of patients of sickle cell patients

\begin{tabular}{lllll}
\hline $\begin{array}{l}\text { Urinary specific } \\
\text { gravity }\end{array}$ & $\begin{array}{l}\text { SCA } \\
(\mathbf{n = 3 2 )} \\
\mathbf{( \% )}\end{array}$ & $\begin{array}{l}\text { SCT } \\
\mathbf{( n = 5 0 )} \\
\mathbf{( \% )}\end{array}$ & $\begin{array}{l}\text { Total } \\
\mathbf{( n = 8 2 )} \\
\mathbf{( \% )}\end{array}$ & p-value \\
\hline $\begin{array}{l}\text { Hypersthenuria } \\
\begin{array}{l}(>1.026) \\
\text { Hyposthenuria }\end{array}\end{array}$ & $18(21.9)$ & $3(6.0)$ & $10(12.2)$ & $<0.001^{* * *}$ \\
$(<1.015)$ & $12(24.0)$ & $30(36.6)$ & \\
\hline *Significant at $\mathrm{P}<0.05$, **Highly significant at $\mathrm{P}<0.01, * * *$ Very highly significant \\
at $\mathrm{P}<0.001$, SCA: Sickle cell anemia, SCT: Sickle cell trait
\end{tabular}

Table 10: Specific gravity of urine in sickle cell crisis patients

\begin{tabular}{lllll}
\hline $\begin{array}{l}\text { Specific Gravity } \\
\text { of urine }\end{array}$ & $\begin{array}{l}\text { SCA } \\
(\mathbf{n = 1 2 )} \\
\mathbf{( \% )}\end{array}$ & $\begin{array}{l}\text { SCT } \\
\mathbf{( n = 9 )} \\
\mathbf{( \% )}\end{array}$ & $\begin{array}{l}\text { Total } \\
(\mathbf{n = 2 1 )} \\
\mathbf{( \% )}\end{array}$ & p-value \\
\hline $\begin{array}{l}\text { Hypersthenuria } \\
(>1.026)\end{array}$ & $4(33.3)$ & $1(11.1)$ & $5(23.8)$ & $0.019^{*}$ \\
$\begin{array}{l}\text { Hyposthenuria } \\
(<1.015)\end{array}$ & $7(58.3)$ & $2(22.2)$ & $9(42.9)$ & \\
\hline
\end{tabular}

*Significant at $\mathrm{P}<0.05,{ }^{* *}$ Highly significant at $\mathrm{P}<0.01,{ }^{* * *}$ Very highly significant at $\mathrm{P}<0.001$, SCA: Sickle cell anemia, SCT: Sickle cell trait

shows a similarity with others' findings [6-8]. Majority of the cases had clinical features of fatigability, dyspnea, joint pain, pallor, icterus, and edema. Pallor was seen in all (100\%) patients. Between two groups, fatigability, dyspnea, and icterus were seen more in SCA patients as compared to SCT patients. All these findings were found to be statistically significant $(\mathrm{p}<0.05)$. According to symptoms and related signs these are more common in SCA than SCT because SCA is more severe than SCT.

Among the SCA patients, majority of the participants $(59.37 \%)$ had $\mathrm{Hb}$ level of range 5-7 g/dl and for SCT, majority (40\%) had $\mathrm{Hb}$ level of 7-9 g/dl. The difference of Hb level among two groups was found to be very highly significant $(\mathrm{p}<0.001)$. Among the SCA, the mean $\mathrm{Hb}$ level was $6.35( \pm 0.89)$ and for SCT it was $9( \pm 0.48)$ indicating a lower average $\mathrm{Hb}$ in SCA groups. Analysis of the above data shows $\mathrm{Hb}$ was found to be on lower side among patients of SCA than SCT, $p<0.001$ and 
Table 11: Prevalence of CKDs among the sickle cell patients

\begin{tabular}{lllll}
\hline Prevalence & $\begin{array}{l}\text { SCA } \\
(\mathbf{n = 3 2 )}\end{array}$ & $\begin{array}{l}\text { SCT } \\
(\mathbf{n = 5 0 )}\end{array}$ & $\begin{array}{l}\text { Total } \\
(\mathbf{n = 8 2})\end{array}$ & p-value \\
& $\mathbf{( \% )}$ & $\mathbf{( \% )}$ & $\mathbf{( \% )}$ & \\
\hline Normal & $20(62.5)$ & $49(98.0)$ & $69(84.1)$ & $<0.001^{* * *}$ \\
CKD & $12(37.5)$ & $1(2.0)$ & $13(15.9)$ & \\
\hline
\end{tabular}

*Significant at $\mathrm{P}<0.05,{ }^{* *}$ Highly significant at $\mathrm{P}<0.01$, ${ }^{* * *}$ Very highly significant at P<0.001, CKD: Chronic kidney disease, SCA: Sickle cell anemia, SCT: Sickle cell trait

Table 12: Prevalence of CKDs among the sickle cell patients in crisis

\begin{tabular}{lllll}
\hline Prevalence & $\begin{array}{l}\text { SCA } \\
(\mathbf{n = 1 2 )}\end{array}$ & $\begin{array}{l}\text { SCT } \\
(\mathbf{n = 9})\end{array}$ & $\begin{array}{l}\text { Total } \\
(\mathbf{n = 2 1 )}\end{array}$ & p-value \\
& $\mathbf{( \% )}$ & $\mathbf{( \% )}$ & $\mathbf{( \% )}$ & \\
\hline Normal & $5(41.7)$ & $8(88.88)$ & $13(61.90)$ & $0.027^{*}$ \\
CKD & $7(58.3)$ & $1(11.12)$ & $8(38.09)$ & \\
\hline
\end{tabular}

*Significant at $\mathrm{P}<0.05,{ }^{* *}$ Highly significant at $\mathrm{P}<0.01,{ }^{* * *}$ Very highly significant at $\mathrm{P}<0.001$, SCA: Sickle cell anemia, SCT: Sickle cell trait

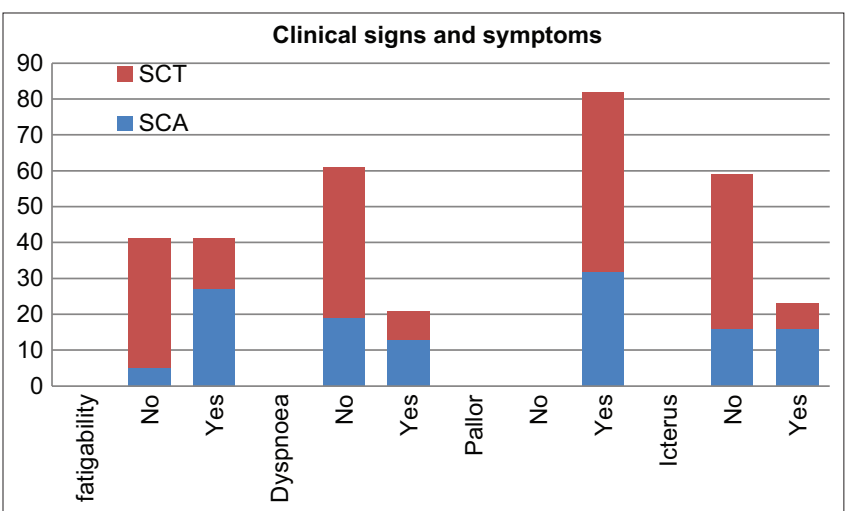

Fig. 2: Clinical symptoms among the study participants between two groups

is very highly significant. This is also explained by the fact that in SCA there is more hemolysis and less production of adult $\mathrm{Hb}$ in comparison to SCT. Patients of SCA and with crisis had more anemia than patients of SCT and patients without crisis, due to amount of increased sickle hemoglobin [6]

Microalbuminuria is an important marker of glomerular injury in patients with SCA and mayalso be demonstrated in someSCT individuals. In the present study, in SCA, 50\% cases had microalbuminuria and $28.1 \%$ had macroalbuminuria as compared to $24 \%$ and $14 \%$ in SCT patients, respectively. Among these data microalbuminuria shows significant p-value (0.015) when compared between SCA and SCT patients. The present study result shows a similarity with the studies by Guasch et al. [10]. In their prospective study by involving 300 adults aged 20-70 years, it was found that the prevalence of albuminuria was $68 \%$ in homozygous individuals versus $32 \%$ in heterozygous patients; in this latter study, $21 \%$ of the patients had RF. Sesso et al. in 1998 found a high prevalence of microalbuminuria in Hb SS patients (30\% vs. $8 \%, p<0.0001)$, mainly in those with a longer duration of disease (49\% in patients older than 15 years) [11]. Aokai and Saad [12] shows that the prevalence rate of proteinuria in patients with $\mathrm{Hb}$ SS has been reported to vary from $17 \%$ to $33 \%$ in studies in which proteinuria was determined by the dipstick method. Alvarez et al. (2008) and Abbate et al. (2006) found that microalbuminuria and albuminuria were common in the SCD and could occur in up to $80 \%$ of patients resulting in a glomerulopathy $[13,14]$. For microalbuminuria in sickle cell crisis patients, the data have significant p-value $(0.027)$ in our study. This suggests more patients in SCA with crisis had microalbuminuria than patients of SCT with crisis.

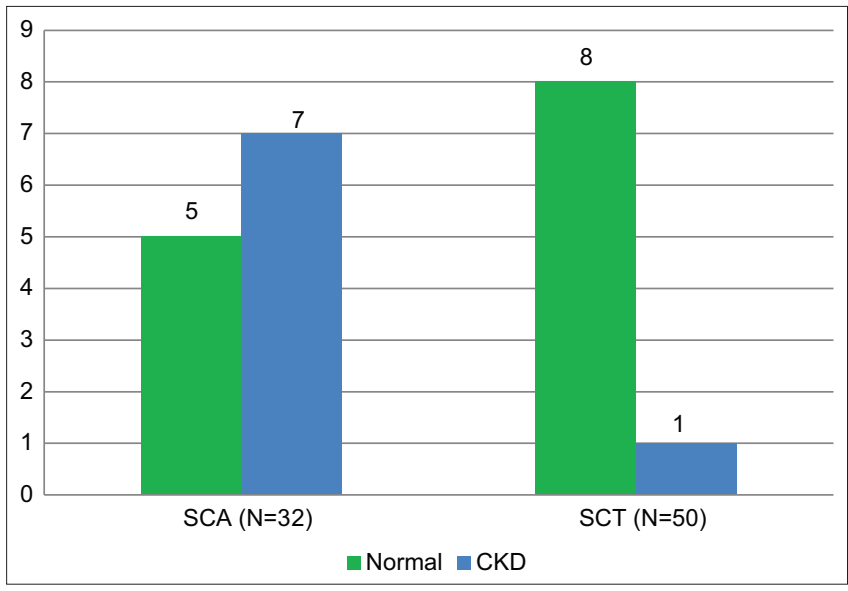

Fig. 3: Prevalence of chronic kidney diseases among the sickle cell patients

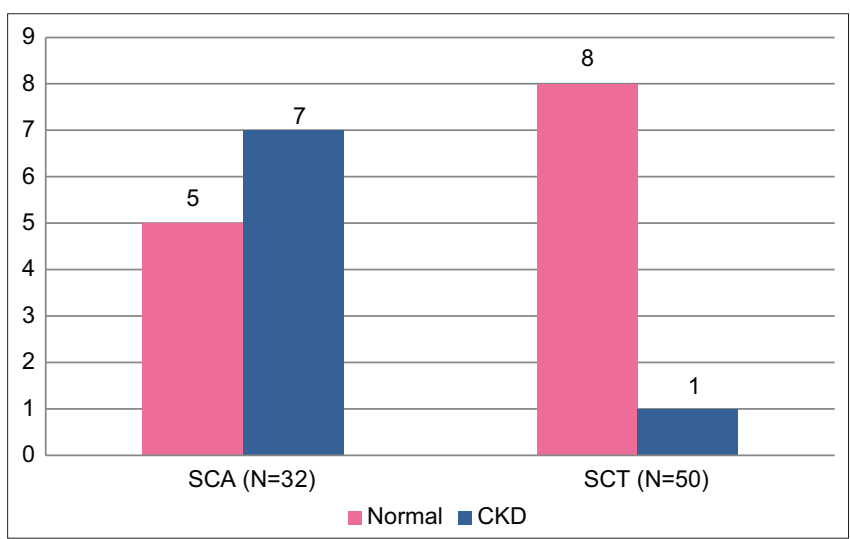

Fig. 4: Prevalence of chronic kidney diseases among the sickle cell patients in crisis

In the present study, out of 21 patients with sickle cell crisis, ten patients (48\%) had significant albuminuria, among which nine patients $(90 \%)$ were SCA cases and one patient $(10 \%)$ was SCT case. Above finding suggest that albuminuria is common in sickle cell patients and there is more chance of getting it in SCA patients.

Painless hematuria (microscopic, macroscopic, or gross) is a common symptom of SCD. Microscopic hematuria was a predominant finding in SCA patients; 15 cases (46.87\%) among the SCT, and eight patients $(16 \%)$ in SCA had hematuria in our study. This data are significant having $\mathrm{p}$ value $<0.05$. In SCA patients with crisis, 11 patients $(91.9 \%)$ had hematuria which was more than SCT patients with crisis, $(n=2,22.2 \%)$. This data have a p-value (0.001) and are very highly significant. The above findings suggest that hematuria occurred both in SCT and sickle cell anemia. But patients of SCA and with crisis had more number of cases of hematuria than SCT and with crisis because SCA had more glomerular and tubular dysfunction along with papillary necrosis and this pathology more severe in crisis cases.

Cast and crystals in urine were found in nine patients $(28.12 \%)$ of SCA and 11 patients (22\%) of SCT. Out of total population $9.7 \%$ had RBC casts, while $21.95 \%$ had granular casts. $31.2 \%$ of SCA patients and $12 \%$ of SCT patients had epithelial cells in urine. In our study, $58.3 \%$ of SCA patients with crisis had tubular epithelial cells in their urine. $50 \%$ of SCA patients and $77.78 \%$ of SCT patients with crisis had casts and crystals in urine. Casts were mostly granular cast, followed by RBC casts. p-value was found to be 0.01 . Above finding suggests interstitial nephritis or glomerular or tubular damage in SCD patients. Wankhade et al. (2012) observed RBCs in 70\%, epithelial cells in $96 \%$ patients 
in microscopic investigation of the urine of SCD. Renal tubular cells were observed in $40 \%$ patients while $11 \%$ patients were infected by bacteria. Yeasts were found in $9 \%$ urine samples. They also observed different normal and abnormal crystal in the urine sample of SCA [15]. We observed Tyrosine in $15 \%$, cholesterol in $16 \%$, phosphate in $40 \%$, sulfamide in $11 \%$, mucus in $2 \%$, while hyline was found in $53 \%$ patients, uric acid in 34\%, oxalate in 53\%, and cystine in 5\% SCA patients.

Hyposthenuria was a predominant finding in patients of sickle cell anemia. In SCA patients, 18 cases (56.2\%) and in SCT patients 12 cases (24\%) had hyposthenuria. In sickle cell crisis patients, $42.9 \%$ had developed hyposthenuria, out of which $58.33 \%$ were SCA patients and $22.2 \%$ were SCT patients. These findings are suggestive of renal medullary ischemia and the renal involvement is more in SCA patients than SCT patients, for which they were passing large amount of diluted urine, which would further contribute to the development of dehydration, leading to further renal ischemia and complications. Keitel et al. found that hyposthenuria is the most common complication associated with the presence of intravascular "S" $\mathrm{Hb}$ [16]. Sesso et al. found in their study urinary osmolality was reduced in patients with $\mathrm{Hb} \mathrm{SS}$ or with $\mathrm{Hb} \mathrm{AS}$; however, it was particularly evident in $\mathrm{Hb}$ SS patients older than 15 years (median = $393 \mathrm{mosmol} / \mathrm{kg}$, range $=366-469 \mathrm{mOsmol} / \mathrm{kg}$ ) compared with $\mathrm{Hb}$ AS patients [11]

SCN is a spectrum of changes resulting from a cascade of events occurring in the kidney. This is triggered by red blood cell vascular occlusion, infarction and reperfusion injury occurring within the renal medullar, cortex, and collecting system. These may present as hyperfiltration, impaired urinary concentrating ability, albuminuria, decreased eGFR, and end-stage kidney disease [17]. In our study, we found 37.5\% SCA patients having CKD and 2\% SCT patients having CKD. This has a p-value of $<0.001$ and very highly significant. From this data it is derived that CKD is a common finding and highly associated in SCA in comparison to SCT. CKD is common in patients with SCD and its prevalence increases with age. At baseline, 28.6\% of patients had CKD in Gosmanova et al. study [18]. Menye et al. in 2019 had the following observations. CKD was found in $16 \%$ patients in the SCA group and 11\% in the SCT group. CKD was found in $37 \%$ of adult SCA patients [17]. However, a $50 \%$ prevalence of CKD in adult SCA was found in Bolarinwa et al. study in Nigeria [19].

\section{Limitations}

Small sample size is a limitation of our study and may not be representative of all the SCD population.

\section{CONCLUSION}

The prevalence of SCD is high in Western and Southern Odisha. In our study, we found that renal involvement is a common manifestation of SCD. Both the sickle cell patients with and without crisis were included in our study. Renal abnormalities were found to be more aggravated in crisis group. Interventions through early stage monitoring and detection may delay progression into advanced stages and end stage renal disease.

\section{AUTHORS' CONTRIBUTIONS}

The authors declare that all the named authors have contributed equally to this article.

\section{CONFLICTS OF INTEREST}

The authors have no conflicts of interest to disclose.

FUNDING

No Funding Sources.

\section{REFERENCES}

1. World Health Organization. Management of Hemoglobin Disorders: Report of Joint WHO-TIF Meeting, Nicosia, Cyprus. Geneva: World Health Organization; 2007.

2. National Health Mission, Guidelines on Hemoglobinopathies in India. Ministry of Health and Family Welfare. India: Government of India; 2016. p. 19.

3. Kar BC, Satapathy RK, Kulozik AE, Kulozic M, Sirr S, Serjeant BE. Sickle cell disease in Orissa State, India. Lancet 1986;2:1198-201.

4. Platt OS, Brambilla DJ, Rosse WF, Milner PF, Castro O, Steinberg MH, et al. Mortality in sickle cell disease. Life expectancy and risk factors for early death. N Engl J Med 1994;330:1639-44.

5. Powars DR, Hiti A, Ramicone E, Johnson C, Chan L. Outcome in haemoglobin SC disease: A four-decade observational study of clinical, hematologic and genetic factors. Am J Hematol 2002;70:206-15.

6. Khan KR, Patil MM. Study of renal profile in patients of sickle cell disease. Int J Sci Res 2018;7:189.

7. Andhale RB, Lodha S, Wankhade V. Renal physiological status of sickle cell anemic patients, district Amravati MS India. J Blood Disordes Transf 2013;5:188.

8. Dhumne UL, Jawade AA. Sickle cell anemia and morbidity in rural population of Chandrapur district Maharashtra, India. Anthropologists 2011;13:61-3.

9. Howard J, Thein SL. Optimal disease management and health monitoring in adults with sickle cell disease. Hematol Am Soc Hematol Educ Prog 2019;2019:505-12.

10. Guasch A, Cua M, You W, Mitch WE. Sickle cell anemia causes a distinct pattern of glomerular dysfunction. Kidney Int 1997;51:826-33.

11. Sesso R, Almeida MA, Figueiredo MS, Bordin JO. Renal dysfunction in patients with sickle cell anemia or sickle cell trait. Braz J Med Biol Res 1998;10:1257-62.

12. Aokai RY, Saad ST. Enalapril reduces the albuminuria of patients with sickle cell disease. Am J Med 1995;98:432-5.

13. Alvarez O, Lopez-Mitnik G, Zilleruelo-G. Short term follow up of patients with sickle cell disease and albuminuria. Pediatr Blood Cancer 2008;50:1236-9.

14. Abbate M, Joja C, Remuzzi G. How does proteinuria cause progressive renal damage? J Am Soc Nephrol 2006;17:2974-84

15. Wankhade V, Andhale RB, Lodha S. Diverse clinical manifestations in sickle cell anemia: Study in district Amravati, MS India. J Blood Disorders Transf 2013;4:136

16. Keitel HG, Thompson D, Itano HA. Hyposthenuria in sickle cell anemia; a reversible renal defect. J Clin Invest 1956;35:998-1007.

17. Menye HD, Wandji G, Kaze FF, Teuwafeu DG, Kane Y, Halle M, et al. Chronic kidney disease in sickle cell disease: Prevalence and associated factors in Cameroon. J Clin Nephrol Ren Care 2019;5:48.

18. Gosmanova EO, Zaidi S, Wan JY, Adams Graves PE. Prevalence and progression of chronic kidney disease in adult patients with sickle cell disease. J Investig Med 2014;62:804-7.

19. Bolarinwa RA, Akinlade KS, Kuti MA, Olawale OO, Akinola NO. Renal disease in adult Nigerians with sickle cell anemia: A report of prevalence, clinical features and risk factors. Saudi J Kidney Dis Transpl 2012;23:171-5. 